\title{
Seasonal and diurnal variations of carbon dioxide and energy fluxes over three land cover types of Nepal
}

\author{
Bharat Badayar Joshi ${ }^{1,2} \cdot$ Yaoming Ma ${ }^{1,2,3}\left(\right.$ CD $\cdot$ Weiqiang Ma ${ }^{1,2,3} \cdot$ Madan Sigdel $^{4} \cdot$ Binbin Wang $^{1,3} \cdot$ Sunil Subba ${ }^{1,2}$
}

Received: 15 December 2018 / Accepted: 21 August 2019 / Published online: 30 August 2019

(C) The Author(s) 2019

\begin{abstract}
This study examines the seasonal and diurnal variations of carbon dioxide and energy fluxes over three land cover types of Nepal by using the eddy covariance method from March to November 2016. The surface energy balance closures were moderate with the values of about $56 \%, 61 \%$, and $64 \%$ closure at Kirtipur, Simara, and Tarahara sites respectively. The monthly average values of net radiation flux and latent heat flux peaked in August at Kirtipur and Tarahara sites whereas in June at the Simara site respectively. The maximum monthly average measured sensible heat flux was $37 \mathrm{~W} \mathrm{~m}^{-2}, 43.6 \mathrm{~W} \mathrm{~m}^{-2}$, and $36.3 \mathrm{~W} \mathrm{~m}^{-2}$ in April for all the sites whereas soil heat flux was $5.1 \mathrm{~W} \mathrm{~m}^{-2}$ and $2.9 \mathrm{~W} \mathrm{~m}^{-2}$ in April for Kirtipur and Simara sites and $6.2 \mathrm{~W} \mathrm{~m}^{-2}$ in June for the Tarahara site. The magnitude of diurnal peak of net ecosystem $\mathrm{CO}_{2}$ exchange (NEE) reached up to $11.04 \mu \mathrm{mol} \mathrm{m}^{-2} \mathrm{~s}^{-1}$ at Kirtipur, $15.04 \mu \mathrm{mol} \mathrm{m}^{-2} \mathrm{~s}^{-1}$ at Simara, and $10.44 \mu \mathrm{mol} \mathrm{m} \mathrm{m}^{-1}$ at Tarahara sites respectively. Among the three study sites, the ecosystem at the Kirtipur site was a good carbon source; the ecosystems at Simara and Tarahara sites were low and good carbon sink in the growing season. In addition, all three different land cover ecosystem were carbon source when accounted for the measurement period.
\end{abstract}

Keywords Eddy covariance measurements $\cdot$ Carbon dioxide flux $\cdot$ Turbulent heat flux $\cdot$ Seasonal and diurnal variations $\cdot$ Nepal

\section{Introduction}

Carbon dioxide $\left(\mathrm{CO}_{2}\right)$ has been recognized as one of the most important greenhouse gases. The increase in the atmospheric concentration of $\mathrm{CO}_{2}$ due to natural and anthropogenic activities is responsible for the warming of the climate, also termed as "global warming" (Rodda et al. 2016). The atmospheric concentration of $\mathrm{CO}_{2}$ has been continuously increasing globally, rising about $48 \%$ from a pre-industrial time to present, i.e., $278 \mathrm{ppm}$ in 1750 to $411 \mathrm{ppm}$ in May 2019 (Climate

Yaoming Ma

ymma@itpcas.ac.cn

1 Key Laboratory of Tibetan Environment Changes and Land Surface Processes, Institute of Tibetan Plateau Research, Chinese Academy of Sciences, No. 16 Lincui Road, Chaoyang 100101, Beijing, China

2 University of Chinese Academy of Sciences, Beijing 100049, China

3 CAS Center for Excellence in Tibetan Plateau Earth Sciences, Beijing 100101, China

4 Central Department of Hydrology and Meteorology, Tribhuvan University, Kathmandu, Nepal
Change: Vital Signs of the Planet 2019). The annual growth rate of $\mathrm{CO}_{2}$ in the recent decade was observed to be higher than the previously measured decadal rates (Stocker et al. 2013). The $\mathrm{CO}_{2}$ exchange between the terrestrial ecosystem and atmosphere is one of the key processes that affect atmospheric $\mathrm{CO}_{2}$ concentration (Saito et al. 2005). The increase in atmospheric $\mathrm{CO}_{2}$ has profound implications for the planet's climate as well as on photosynthesis and the structure and function of plant communities (Woodward 1998; Mielnick et al. 2001). Thus, information on the exchange of $\mathrm{CO}_{2}$ fluxes between atmosphere and ecosystem is necessary to better understand the potential of those ecosystems in reducing the rise in the atmospheric concentration of $\mathrm{CO}_{2}$ and ultimately mitigating the climate change (Robertson et al. 2000).

In the ecological processes, energy fluxes are regarded as the most crucial components related to carbon sequestration in terrestrial ecosystems (Baldocchi 1997; Dugas et al. 1999). The vital ecosystem processes, such as plant photosynthesis and vegetation productivity, are associated with energy fluxes (Hao et al. 2007). Energy fluxes are key parameters in climate simulations. The seasonal and diurnal variations in surface partitioning of available energy, i.e., the difference between the net radiation $(\mathrm{Rn})$ and soil heat flux, into sensible heat flux 
(H) and latent heat flux (LE) influence the climatic simulations (Dickinson et al. 1991). Sensible and latent heat fluxes are key variables in energy and water vapor exchanges between the land surface and atmosphere. They are also the drivers of the Earth's major water, energy, and biogeochemical cycles (Gentine et al. 2012; Xu et al. 2014). Concurrently, it also governs the evolution and characteristics of the planetary boundary layer, such as its depth, thermodynamic behavior, the surface air temperature, and humidity (Schmid et al. 1991; Beringer and Tapper 2002). Investigation of energy exchanges in different ecosystems helps to understand the mechanisms that control the carbon cycle and ecosystem processes (Hao et al. 2007). Therefore, measurements of $\mathrm{CO}_{2}$ and energy fluxes across the vegetation-atmosphere interface are essential to understand different processes controlling the carbon storage in the vegetative systems.

In the context of Nepal, few studies have been conducted in the field of $\mathrm{CO}_{2}$ and energy fluxes to know their attributes in the current climate change. The studies on distributions, and the seasonal and diurnal variations of carbon dioxide and land surface energy fluxes (net radiation flux, sensible heat flux, latent heat flux, and soil heat flux) in the southern slope of Himalaya, such as Nepal, have been in a very poor stage until now. So, this study mainly focuses on the analysis of seasonal and diurnal variations of the aforementioned elements along with $\mathrm{CO}_{2}$ fluxes over three different land cover types of Nepal. Specifically, our study aims to answer the following questions: (a) what is the seasonal and diurnal variation of $\mathrm{CO}_{2}$ and energy fluxes over three land cover types of Nepal? (b) How can this variability be inter-compared seasonally and on different land cover types of Nepal?

\section{Materials and methods}

\subsection{Study sites}

The study area comprises three different sites in Nepal, which is a country of contrast with high variation in altitude, climate, and vegetation within the small latitudinal difference. The three study sites where measurements were carried out are Kirtipur, Simara, and Tarahara. Geographically, the Kirtipur site lies in the mid-hills region, whereas Simara and Tarahara sites lie in the lowland region (also called as Terai) of Nepal. Simara and Tarahara sites are typically dominated by subtropical climatic make up and highly influenced by the southwestern monsoon whereas, the temperate climatic condition is found in Kirtipur. The descriptive and figurative information about location, date of establishment, data period, data gaps, and landscape of flux towers of these sites are presented in Table 1 and Fig. 1a and b.

The Kirtipur site is located at $27.68^{\circ} \mathrm{N}$ latitude and $85.29^{\circ}$ E longitude, with an elevation of $1318 \mathrm{~m}$ a.s.l. The station lies inside the Tribhuvan University premises in the suburban area of Kathmandu Valley. Sparse trees and scattered buildings can be seen around the station. The grasses and bushes around the station are mainly dominant in the growing season. The main metropolitan area is nearly $1 \mathrm{~km}$ far from the station location, whereas the Kirtipur settlement area is within $500 \mathrm{~m}$ from the station. From 1971 to 2014, the average minimum and maximum temperatures of 6.6 and $16.9^{\circ} \mathrm{C}$ with an average annual rainfall of $1666.6 \mathrm{~mm}$ were recorded for this site (DHM 2017). Gautam and Bhattarai (2013) reported that the soil found at this site is a mixture of sand and clays and slightly alkaline in nature.

The Simara site is located at $27.16^{\circ} \mathrm{N}$ latitude and $84.98^{\circ} \mathrm{E}$ longitude, with an elevation of $137 \mathrm{~m}$ a.s.l. The station lies inside the Simara airport premises. Besides the runway of the airport, the area around the station is mainly covered by grassland. The local area around the site has a number of scattered houses and planted trees. From 1971 to 2014, the average minimum and maximum temperature of 18.4 and $30.5^{\circ} \mathrm{C}$ with an average annual rainfall of $1692.3 \mathrm{~mm}$ were recorded for this site (DHM 2017). Khadka et al. (2018) found that the soil at the Simara site was moderately acidic in $\mathrm{pH}(5.67 \pm 0.09)$, low in organic matter $(0.74 \pm 0.04 \%)$, and available Sulfur $(0.8 \pm 0.1 \mathrm{ppm})$. The sand, silt, and clay contents were 24.41 $\pm 0.59 \%, 54.57 \pm 0.44 \%$, and $21.03 \pm 0.32 \%$, respectively and categorized as silt loam and loam in texture.

The Tarahara site is located at $26.70^{\circ} \mathrm{N}$ latitude, and $87.28^{\circ}$ E longitude, with an elevation of $120 \mathrm{~m}$ a.s.l. The cropping field surrounds the tower, and crop rotation is the major practice in this area. Major crop species used in the crop rotation are paddy (June-October), wheat (October-March), and maize (March-June). The crop types are the same for the land around the tower at a distance of approximately $300 \mathrm{~m}$ (Acharya et al. 2019). Therefore, the turbulent fluxes from all the directions are homogeneous. From 1971 to 2014, the average minimum and maximum temperatures of 18.6 and $30.1^{\circ} \mathrm{C}$ with an average annual rainfall of $1794.3 \mathrm{~mm}$ were recorded for this site (DHM 2017). Khadka et al. (2017) reported that the soil at the Tarahara site was moderately acidic in nature, and the organic matter $(2.80 \pm 0.07 \%)$ contained $30.32 \%$ sand, $48.92 \%$ silt, and $20.76 \%$ clay.

\subsection{Micrometeorological measurements}

The eddy covariance (EC) systems were set up jointly by the Tribhuvan University, and the Institute of Tibetan Plateau Research, Chinese Academy of Sciences at Simara and Tarahara sites, and a 40-m-tall planetary boundary layer (PBL) tower was set up at the Kirtipur site in order to install the sensors that measure the different meteorological variables.

Relative humidity and air temperature were measured at 40 $\mathrm{m}, 6 \mathrm{~m}$, and $3 \mathrm{~m}$ above the ground level by using a relative 
Table 1 Data description of study sites

\begin{tabular}{lccccc}
\hline Study site & Latitude $\left({ }^{\circ} \mathrm{N}\right)$ & Longitude $\left({ }^{\circ} \mathrm{E}\right)$ & Elevation $(\mathrm{m}$ a.s.l.) & Date of establishment & Data period \\
\hline Kirtipur & 27.68 & 85.29 & 1318 & February 2016 & March-November 2016 \\
Simara & 27.16 & 84.98 & 137 & February 2016 & March-November 2016 \\
Tarahara & 26.70 & 87.28 & 120 & October 2012 & March-November 2016 \\
\hline
\end{tabular}

humidity sensor (HMP45C, Vaisala) at Kirtipur, Simara, and Tarahara sites respectively. A propeller anemometer (014A-L, Met One) was used to measure the wind speed and wind direction at the same heights. Soil moisture and soil temperature were measured by using temperature probes (Campbell Scientific Inc. Model 109) and a time-domain reflectometry (TDR) system (Campbell Scientific Inc. probe type CS616) respectively at depths of 5, 10, and $20 \mathrm{~cm}$.

Fig. 1 a Eddy covariance station (study sites) locations on the map of Nepal. b Landscape and flux towers at (a) Kirtipur site, (b) Simara site, and (c) Tarahara site

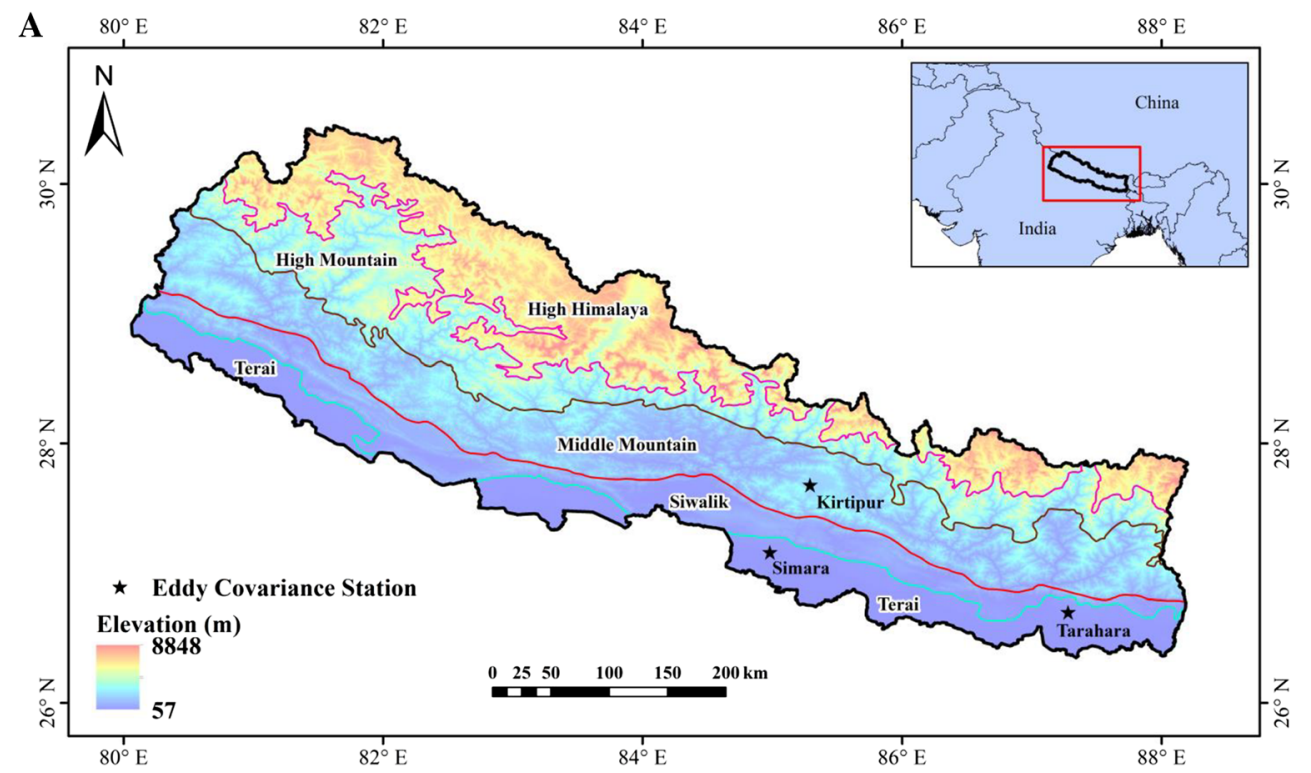

B

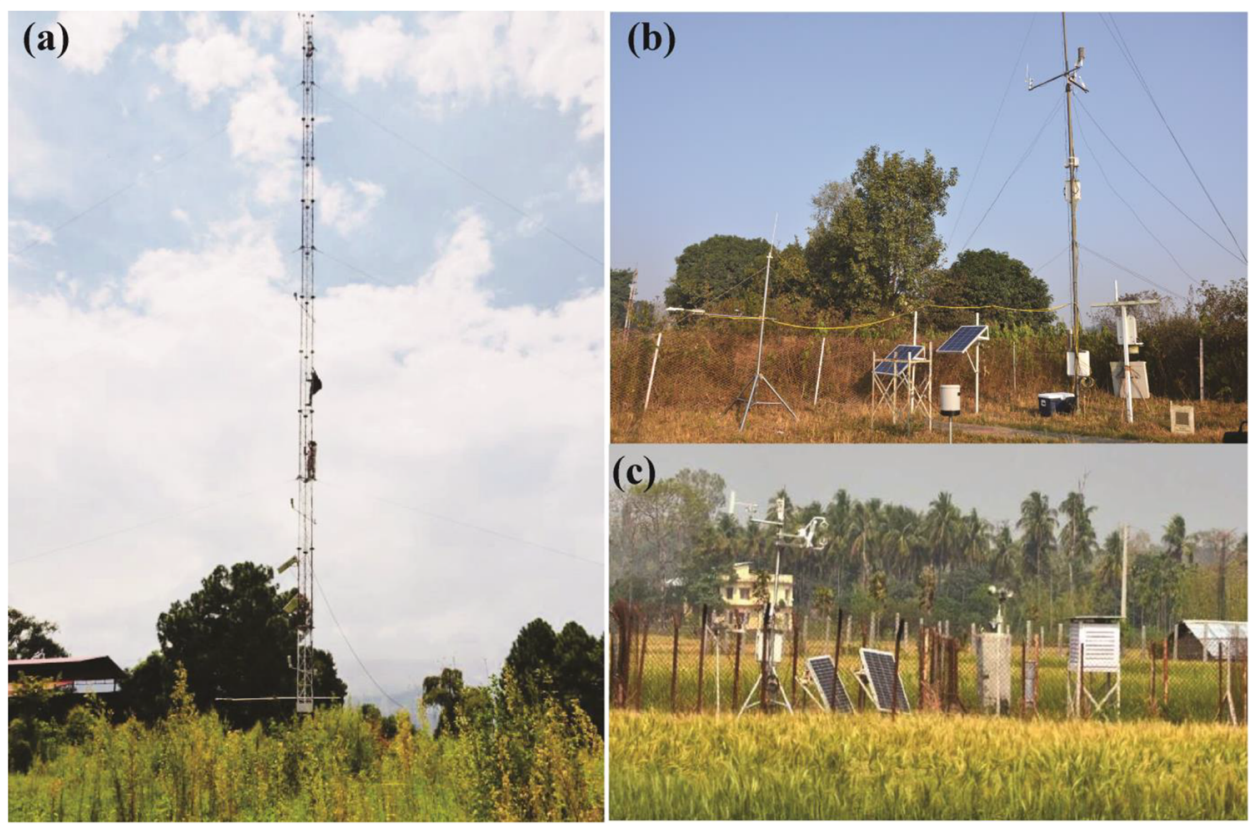


Hukseflux soil heat flux plates measured the soil heat flux at a depth of $5 \mathrm{~cm}$. Precipitation was recorded at around $0.5 \mathrm{~m}$ above the ground level by using tipping rain bucket. The net radiometer (CNR 4, Kipp \& Zonen) was installed $1.5 \mathrm{~m}$ above the ground level that consisted of upward and downward facing pyrgeometers and pyranometers. Pyrgeometers were used for recording incoming and outgoing longwave radiation whereas pyranometers recorded the incoming and outgoing shortwave radiation (Acharya et al. 2019).

The net radiometer sensor requires recalibration every 2 years for quality assurance. As the sensors at Kirtipur and Simara stations were installed in February 2016, the data acquisitioned need not go through recalibration. Although, the radiation sensor at Tarahara station was old, and the data recorded by that sensor has already been used by Acharya et al. (2019) in their study, so the data from this station could also be used and analyzed.

\subsection{Eddy covariance measurements}

Eddy covariance towers were installed to measure $\mathrm{CO}_{2}$ and energy fluxes using the open-path EC method in three different land cover types of Nepal. For all sites, we used an openpath infrared gas analyzer (IRGA, LI7500, LI-COR) to measure the $\mathrm{CO}_{2}$ and water vapor concentration, and a threedimensional sonic anemometer (CSAT3, Campbell Scientific Inc.) to measure three-dimensional wind velocities and virtual air temperature. These sensors were installed at $40 \mathrm{~m}, 6 \mathrm{~m}$, and $3 \mathrm{~m}$ above the ground level at Kirtipur, Simara, and Tarahara sites respectively. Quantum sensor (LI-190SB, LI-COR) was used to measure the incident photosynthetic active radiation (PAR). In this study, we handled and analyzed the measurements of $\mathrm{CO}_{2}$ and energy fluxes from March 2016 to November 2016 for all sites.

All these data were recorded with a sampling frequency of $10 \mathrm{~Hz}$. The raw data and the 30-min averaged flux data used in our study were logged by a CR-3000 data logger (Campbell Scientific Inc.) and were stored in a compact flash card. The EC system only corrected effects of air density by using the Webb, Pearman, and Leuning (WPL) correction (Webb et al. 1980).

It is difficult to determine the accuracy of the turbulent fluxes. Thus, previous studies have compared the results of different devices following an experiment and sonic anemometer designed by Zhang et al. (1986) was recommended for better results (Foken and Oncley 1995). The CSAT3 device used in our study is a similar device, and both types resulted in excellent agreement (Mauder 2002). Both CSAT3 and sonic anemometer are classified as type A for their best data quality (Foken and Oncley 1995). Thus, for the accurate flux measurements, these devices, as well as the classification of the data according to their quality, can be used (Foken et al. 2004).

\subsection{Data processing and gap filling}

The half-hourly net ecosystem $\mathrm{CO}_{2}$ exchange (NEE), LE, and $\mathrm{H}$ were recalculated from the high-frequency raw data by using the TK3 software package (Mauder and Foken 2011). This software has the ability to remove spikes (Mahrt et al. 2012), planar fit rotation (Wilczak et al. 2001), crosswind correction of sonic temperature (Liu et al. 2001), and correct the high and low-frequency losses (Moore 1986). A quality file was created for all 30-min averaged data, with a quality flag ranging from 1 to 9 (Foken et al. 2004). Data with quality flag ranging from 1 to 3 were high-quality data and can be used in fundamental research. Similarly, the data with quality flag ranging from 4 to 6 were the moderate quality data and can be used in long-term observation programs, whereas 6 to 9 were considered the lowest quality data and were excluded (Mauder et al. 2013). The gaps in the data were about $13.07 \%$ for the Kirtipur site, $14.84 \%$ for the Simara site, and $19.56 \%$ for the Tarahara site during the study period. The data gaps were probably due to system failure, bad quality observations, and data rejection. The online package "Reddyproc" tool developed at the Max Planck Institute for Biogeochemistry, Jena, Germany (Reichstein et al. 2005; Moffat et al. 2007) was used for gap filling of flux data. Interpolations, mean diurnal variation, look-up tables, and regression techniques were used to fill the missing data. However, since the data was not available for a long period, we were not able to fill the micrometeorological data and some fluxes data. Thus, the handled and analyzed data contains information gaps (Figs. 3, 5, 7, and 8). The partitioning of NEE into gross primary production (GPP) and ecosystem respiration (ER) was done by using the regression constructed by plotting nighttime NEE versus soil temperature.

\subsection{Random error estimation}

The direct calculation of the variance of the covariance is a powerful and inclusive method for estimating the random sampling error in EC measurements (Finkelstein and Sims 2001). Finkelstein and Sims (2001) suggested the methods of flux uncertainty estimation based on raw data and was implemented by Mauder et al. (2013). We have applied the same methodology to estimate the random error component of representative eddy correlation flux measurements of sensible heat, latent heat, and carbon dioxide over three study sites.

In Fig. 2 the random error is placed in the context of the assigned quality flag for all fluxes. The flagged values are typically associated with larger relative errors, which were in agreement from a meaningful flagging scheme. Except for $\mathrm{CO}_{2}$ flux at the Tarahara site, highest quality data (flags 1-3) are typically associated with random errors of less than $20 \%$. Medium-quality data (flags 4-6) are typically associated with random errors between 14 and 34\%. Lowest quality data 

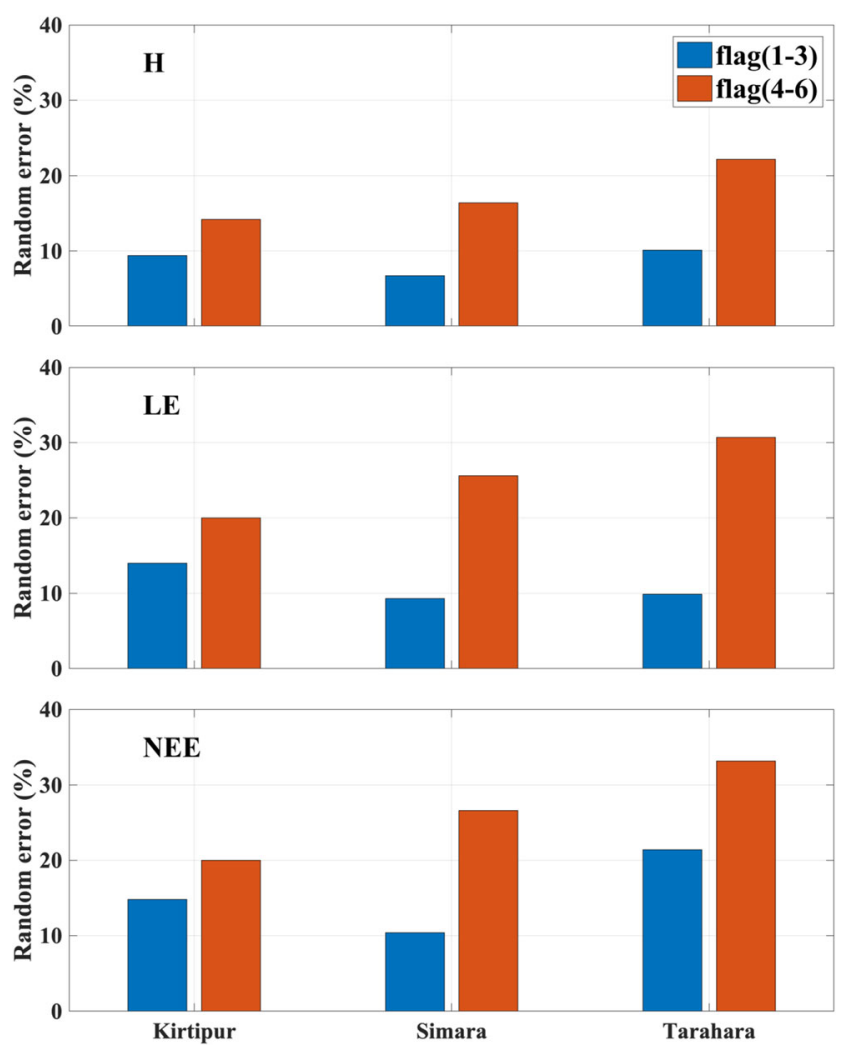

Fig. 2 Mean random flux errors (\%) for the fluxes of sensible heat $(\mathrm{H})$, latent heat (LE), and NEE at three study sites as a function of their quality flag

(flags 6-9) were considered with even larger errors which are not shown in Fig. 2 because the error quantification itself may become questionable.

\subsection{Footprint analysis}

The representative of the source area or flux footprint is one of the criterion of the quality assessment strategy (Schmid 1997). We decided to use the model of Kormann and Meixner (2001) since it is an analytical, numerically robust model, including a crosswind distribution, and it is computationally sufficient fast to be applied for every 30 -min interval in a long measurement. Land cover map with a 30-m resolution for all the sites was the basis for the footprint analysis. The flux contribution from the target area of interest was $80 \%, 72 \%$, and $93 \%$ for Kirtipur, Simara, and Tarahara sites, respectively.

The footprint result shows that about $80 \%$ measured flux is contributed from the vegetation area, rest is contributed from the settlement area at the Kirtipur site. At the Simara site, more than $70 \%$ measured flux is from the grassland area, only a few percentages contributed from the built-up and bare areas. Similarly, at the Tarahara site more than $90 \%$ measured flux is from cropland and, only a small percentage contributed from shrubland and buildings around observation tower. If a flux contribution from the target type of land use is more than $70 \%$, then it is considered as representative for the respective land use type (Mauder et al. 2013). Therefore, the footprint estimates confirmed that the measured flux represents the result of suburban, grassland, and cropland ecosystem at Kirtipur, Simara, and Tarahara sites, respectively.

\section{Results}

\subsection{Meteorological conditions}

The daily average patterns of air temperature (Ta), soil temperature (Ts $5 \mathrm{~cm}, 10 \mathrm{~cm}$, and $20 \mathrm{~cm}$ ), soil moisture (VWC 5 $\mathrm{cm}, 10 \mathrm{~cm}$, and $20 \mathrm{~cm}$ ), precipitation, and vapor pressure deficit (VPD), for all the three sites during the study period can be seen in Fig. 3. The monthly sum of precipitation and averaged values of all other meteorological parameters are presented in Table 2. The monthly averaged values of air temperature ranged from 17.29 to $25.42{ }^{\circ} \mathrm{C}, 22.3$ to 32.32 ${ }^{\circ} \mathrm{C}$, and 23.16 to $32.72{ }^{\circ} \mathrm{C}$ at Kirtipur, Simara, and Tarahara sites respectively. The maximum average monthly air temperature was found in August at Kirtipur and Tarahara sites and in June at the Simara site. The minimum air temperature was recorded in November at all sites. The monthly mean patterns of soil temperature $(5 \mathrm{~cm}, 10 \mathrm{~cm}$, and $20 \mathrm{~cm})$ were also similar to air temperature at all the study sites (Fig. 3).

The pattern of precipitation was almost similar at all the study sites, and the maximum rainfall was received during the growing season (May to September). Kirtipur (425.71 mm) and Simara $(682.76 \mathrm{~mm})$ sites received maximum precipitation in July, whereas no precipitation was recorded for both sites in April. Similarly, the Tarahara site received maximum precipitation of $589 \mathrm{~mm}$ in June, and no precipitation was recorded in November (Table 2). The soil moisture was found maximum in September at all sites and minimum in April at Kirtipur and Simara site, and in March at the Tarahara site (Table 2). All the study sites showed similar trends in soil moisture fluctuations corresponding to rainfall events (Fig. 3 ). The monthly mean VPD was found lower during the growing season and reached its maximum in April at all the study sites (Table 2).

\subsection{Energy balance closure}

The energy balance closure (EBC) provides the plausibility of fluxes that were measured from the eddy covariance measurement system (Wagle et al. 2015). The half-hourly data of the study period were used for the calculation of EBC in the presence of all the four parameters (net radiation, latent heat flux, sensible heat flux, and soil heat flux). The canopy storage energy and the energy used in photosynthesis were not taken into consideration during the calculation of EBC. Figure 4 
Fig. 3 Average daily variations of vapor pressure deficit (VPD), air temperature $(\mathrm{Ta})$, soil temperature (Ts $5 \mathrm{~cm}, 10 \mathrm{~cm}, 20 \mathrm{~cm}$ ), soil moisture (VWC $5 \mathrm{~cm}, 10 \mathrm{~cm}, 20$ $\mathrm{cm}$ ), and precipitation (PPT) for days of the year (DOY) 61-335 (March 1, 2016 to November 30, 2016) at a Kirtipur site, b Simara site, and $\mathbf{c}$ Tarahara site (incomplete lines indicate the data gap)
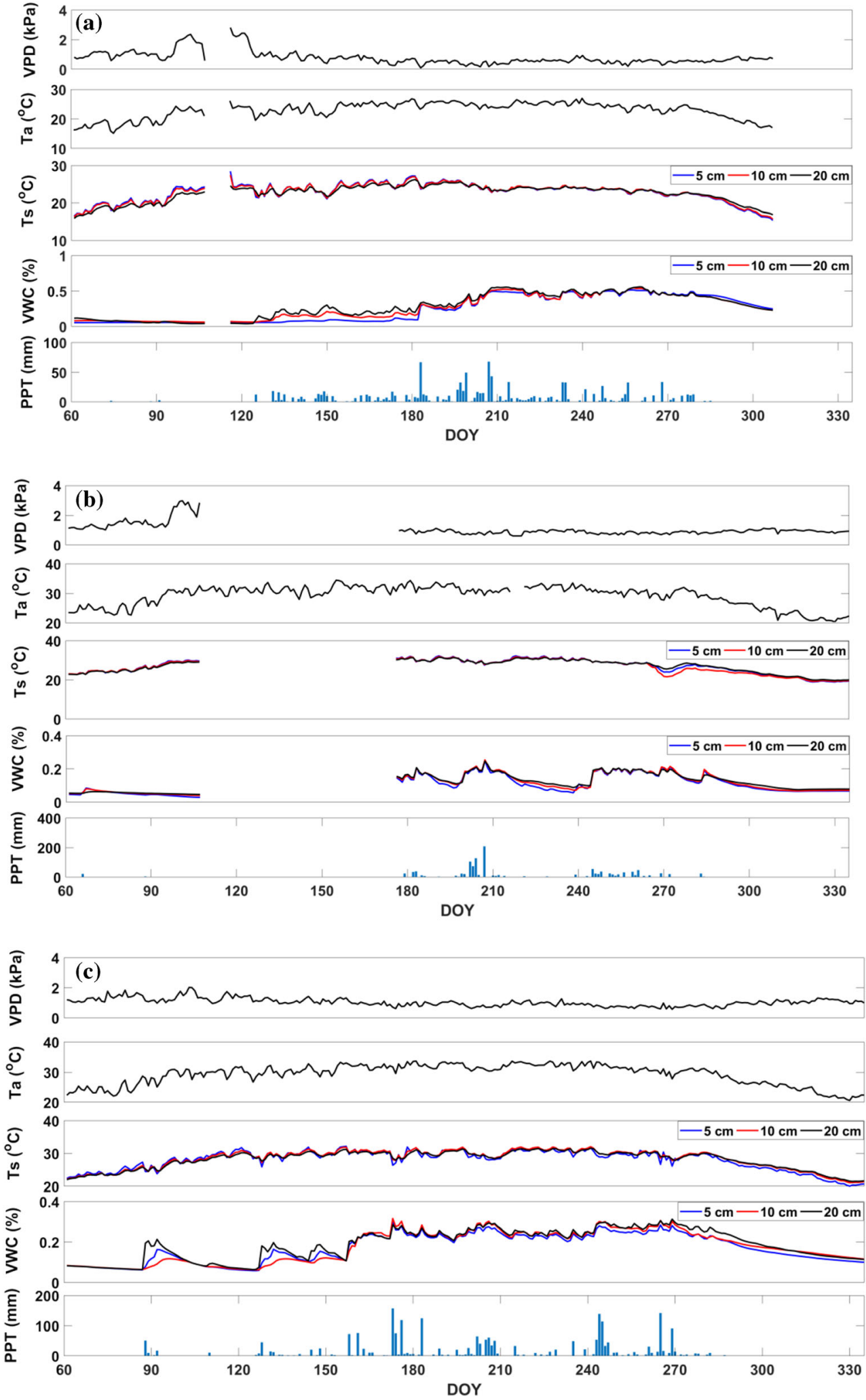

represents the energy closure of three study sites. Specifically, the energy balance closures were moderate with the values of about $56 \%, 61 \%$, and $64 \%$ (the intercepts of $27.4 \mathrm{~W} \mathrm{~m}^{-2}$, $15.4 \mathrm{~W} \mathrm{~m}^{-2}$, and $31.2 \mathrm{~W} \mathrm{~m}^{-2}$, and the coefficient of determination $\left(r^{2}\right)$ of $0.78,0.88$, and 0.89$)$ at Kirtipur, Simara, and Tarahara sites, respectively. The regression coefficient statistics of the energy balance closure for all sites is presented in Table 3. 
Table 2 Monthly average values of air temperature $\left(\mathrm{Ta},{ }^{\circ} \mathrm{C}\right)$, soil temperature (Ts $5 \mathrm{~cm}, 10 \mathrm{~cm}, 20 \mathrm{~cm}$; ${ }^{\circ}$ ), , soil moisture (VWC $5 \mathrm{~cm}$, $10 \mathrm{~cm}, 20 \mathrm{~cm}$; \%), vapor pressure deficit (VPD, kPa), and monthly precipitation (PPT, $\mathrm{mm}$ ) for the three study sites during the study period (**missing data due to malfunction of the sensors and power supply)

\begin{tabular}{|c|c|c|c|c|c|c|c|c|c|c|}
\hline Months & Study sites & $\mathrm{Ta}\left({ }^{\circ} \mathrm{C}\right)$ & Ts $(5 \mathrm{~cm})$ & Ts $(10 \mathrm{~cm})$ & Ts $(20 \mathrm{~cm})$ & VWC $(5 \mathrm{~cm})$ & VWC $(10 \mathrm{~cm})$ & VWC (20 cm ) & VPD (kPa) & PPT (mm) \\
\hline \multirow[t]{3}{*}{ March } & Kirtipur & 18.11 & 19.28 & 19.11 & 18.56 & 0.06 & 0.08 & 0.08 & 1.00 & 6.10 \\
\hline & Simara & 25.10 & 24.64 & 24.66 & 24.39 & 0.06 & 0.06 & 0.06 & 1.34 & 26.17 \\
\hline & Tarahara & 24.71 & 24.41 & 24.00 & 23.86 & 0.08 & 0.07 & 0.09 & 1.31 & 62.30 \\
\hline \multirow[t]{3}{*}{ April } & Kirtipur & 22.86 & 23.66 & 23.32 & 22.38 & 0.06 & 0.07 & 0.05 & 1.77 & 0.00 \\
\hline & Simara & 30.60 & 29.17 & 28.94 & 28.45 & 0.04 & 0.05 & 0.05 & 2.18 & $* *$ \\
\hline & Tarahara & 29.71 & 28.59 & 28.26 & 27.88 & 0.10 & 0.09 & 0.11 & 1.37 & 28.00 \\
\hline \multirow[t]{3}{*}{ May } & Kirtipur & 22.54 & 23.31 & 23.32 & 23.05 & 0.07 & 0.13 & 0.18 & 0.91 & 160.53 \\
\hline & Simara & 30.77 & $* *$ & $* *$ & $* *$ & $* *$ & $* *$ & $* *$ & $* *$ & $* *$ \\
\hline & Tarahara & 30.02 & 29.57 & 29.75 & 29.41 & 0.12 & 0.10 & 0.14 & 1.14 & 151.10 \\
\hline \multirow[t]{3}{*}{ June } & Kirtipur & 25.05 & 25.35 & 25.22 & 24.70 & 0.09 & 0.15 & 0.21 & 0.64 & 128.27 \\
\hline & Simara & 32.32 & 31.32 & 31.13 & 30.79 & 0.14 & 0.15 & 0.15 & 0.99 & 59.45 \\
\hline & Tarahara & 32.09 & 30.28 & 30.47 & 30.03 & 0.21 & 0.22 & 0.22 & 0.96 & 589.00 \\
\hline \multirow[t]{3}{*}{ July } & Kirtipur & 24.90 & 24.70 & 24.68 & 24.53 & 0.34 & 0.36 & 0.39 & 0.40 & 425.71 \\
\hline & Simara & 31.48 & 29.94 & 29.88 & 29.77 & 0.16 & 0.17 & 0.17 & 0.86 & 682.76 \\
\hline & Tarahara & 31.87 & 29.59 & 30.03 & 29.80 & 0.24 & 0.25 & 0.25 & 0.87 & 540.10 \\
\hline \multirow[t]{3}{*}{ August } & Kirtipur & 25.42 & 23.96 & 24.04 & 23.92 & 0.45 & 0.46 & 0.48 & 0.61 & 214.63 \\
\hline & Simara & 32.11 & 30.97 & 30.79 & 30.56 & 0.09 & 0.11 & 0.12 & 0.89 & 46.48 \\
\hline & Tarahara & 32.72 & 30.77 & 31.31 & 31.02 & 0.23 & 0.24 & 0.25 & 0.96 & 360.30 \\
\hline \multirow[t]{3}{*}{ September } & Kirtipur & 23.75 & 23.05 & 23.13 & 23.13 & 0.48 & 0.49 & 0.49 & 0.49 & 158.76 \\
\hline & Simara & 30.09 & 27.65 & 27.06 & 28.04 & 0.19 & 0.19 & 0.19 & 0.79 & 406.14 \\
\hline & Tarahara & 30.77 & 29.24 & 29.77 & 29.60 & 0.26 & 0.28 & 0.28 & 0.73 & 579.90 \\
\hline \multirow[t]{3}{*}{ October } & Kirtipur & 20.90 & 19.92 & 20.11 & 20.54 & 0.39 & 0.36 & 0.36 & 0.62 & 50.55 \\
\hline & Simara & 28.07 & 25.62 & 24.24 & 26.08 & 0.12 & 0.13 & 0.13 & 0.91 & 27.93 \\
\hline & Tarahara & 28.09 & 27.31 & 28.01 & 28.01 & 0.19 & 0.20 & 0.22 & 0.89 & 32.20 \\
\hline \multirow[t]{3}{*}{ November } & Kirtipur & 17.29 & $* *$ & $* *$ & $* *$ & $* *$ & $* *$ & $* *$ & $* *$ & $* *$ \\
\hline & Simara & 22.30 & 20.26 & 20.32 & 20.95 & 0.07 & 0.07 & 0.08 & 0.95 & 2.03 \\
\hline & Tarahara & 23.16 & 22.31 & 23.14 & 23.45 & 0.12 & 0.14 & 0.14 & 1.11 & 0.00 \\
\hline
\end{tabular}

\subsection{Diurnal and seasonal dynamics of energy fluxes}

Table 4 depicts the monthly averaged values of energy fluxes and the Bowen ratio. Over the entire study period, the monthly diurnal values of all energy fluxes were peak at mid-day. The energy fluxes changed seasonally corresponding to the variation of Rn, as shown in Fig. 5. The values of Rn were highest in August at Kirtipur and Tarahara sites and in June at the Simara site. The $\mathrm{LE}$ and $\mathrm{H}$ were maximum in August and April, and minimum in March and September, respectively for all the sites. The monthly averaged values of net radiation and latent heat flux were highest in August at the Kirtipur site $\left(148.5 \mathrm{~W} \mathrm{~m}^{-2}\right.$ and $\left.95.4 \mathrm{~W} \mathrm{~m}^{-2}\right)$ and the Tarahara site $\left(158.1 \mathrm{~W} \mathrm{~m}^{-2}\right.$ and $\left.127.2 \mathrm{~W} \mathrm{~m}^{-2}\right)$, whereas in June at the Simara site $\left(185.1 \mathrm{~W} \mathrm{~m}^{-2}\right.$ and $103.7 \mathrm{~W}$ $\mathrm{m}^{-2}$ ) (Table 4). The maximum monthly averaged measured sensible heat flux was $37 \mathrm{~W} \mathrm{~m}^{-2}, 43.6 \mathrm{~W} \mathrm{~m}^{-2}$, and $36.3 \mathrm{~W} \mathrm{~m}^{-2}$ in April for all the sites, whereas soil heat flux was $5.1 \mathrm{~W} \mathrm{~m}^{-2}$ and $2.9 \mathrm{~W} \mathrm{~m}^{-2}$ in April for Kirtipur and Simara sites, and $6.2 \mathrm{~W} \mathrm{~m}^{-2}$ in June for the Tarahara site (Table 4).

Overall, among three study sites, monthly LE was highest at the Tarahara site and lowest at the Kirtipur site. Furthermore, there was no significant difference in net radiation at Simara and Tarahara sites, but the values were higher than the Kirtipur site. The averaged soil heat flux was usually very low at all sites at the monthly scale, with negative values during September to November and small positive values in other months. The Bowen ratio reached its maximum in March for Kirtipur and Simara sites, and in April for the Tarahara site. Similarly, minimum Bowen ratios were observed in July, October, and August for Kirtipur, Simara, and Tarahara sites, respectively, with the average Bowen ratio of $0.46,0.32$, and 0.23 within the study period for the respective sites. 
Fig. 4 Relation between the difference of net radiation $(\mathrm{Rn})$ and soil heat flux $(\mathrm{G})$, and the sum of latent heat flux (LE) and sensible heat flux $(\mathrm{H})$ at a Kirtipur, b Simara, and $\mathbf{c}$ Tarahara sites during the study period. Points represent data collected for half hour intervals. The solid lines represent the best fit line for linear regression
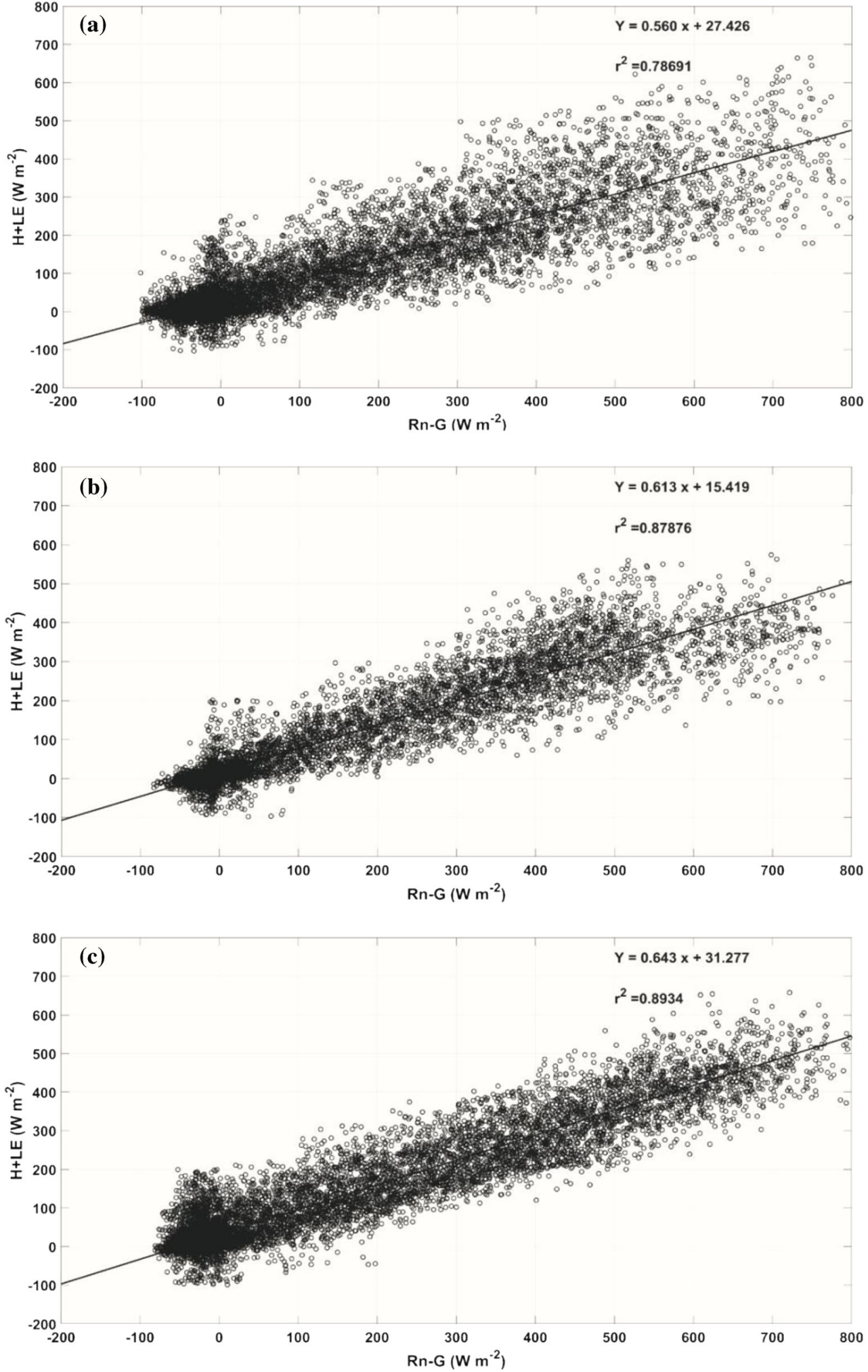

\subsection{Diurnal and seasonal dynamics of NEE}

The diurnal trend of NEE on three land cover types of Nepal from March 2016 to November 2016 is shown in Fig. 6. The maximum $\mathrm{CO}_{2}$ uptake rates were observed at around noon during the growing season at all the study sites. Figure 6 shows that NEE were negative after dawn, gradually decreasing to a minimum around noon and then sharply increasing to 
Table 3 Ordinary linear regression coefficients for energy balance closure for all sites (*EBR energy balance closure)

\begin{tabular}{lccc}
\hline Study sites & Intercept $\left(\mathrm{W} \mathrm{m}^{-2}\right)$ & $r^{2}$ & EBR* \\
\hline Kirtipur & 27.4 & 0.78 & 0.56 \\
Simara & 15.4 & 0.88 & 0.61 \\
Tarahara & 31.2 & 0.89 & 0.64 \\
\hline
\end{tabular}

positive after dusk at all study sites. Considerable variations in the diurnal pattern of NEE were found among the growing season between the three sites. The NEE rates followed the order of Simara $>$ Tarahara $>$ Kirtipur. The magnitude of diurnal peak of NEE reached up to $11.04 \mu \mathrm{mol} \mathrm{m}{ }^{-2} \mathrm{~s}^{-1}$ at the Kirtipur site, $15.04 \mu \mathrm{mol} \mathrm{m} \mathrm{m}^{-2} \mathrm{~s}^{-1}$ at the Simara site, and $10.44 \mu \mathrm{mol} \mathrm{m}^{-2} \mathrm{~s}^{-1}$ at the Tarahara site, respectively (Fig. 6).

The seasonal variations of the daily average of NEE, ER, and GPP on three land cover types from March 2016 to November 2016 are presented in Fig. 7. The positive fluxes of NEE represent the loss of $\mathrm{CO}_{2}$ to the atmosphere (source), whereas negative values indicate net sequestration by the ecosystem (sink). ER represents the net release of $\mathrm{CO}_{2}$ from the ecosystem to the atmosphere, and GPP represents the net sequestration (sink) by the ecosystem (Rodda et al. 2016).

During the study period, the magnitude of daily mean values of NEE ranged from -1.1 to $4.1 \mathrm{~g} \mathrm{C} \mathrm{m}^{-2}$ day $^{-1}$, 2.4 to $5.2 \mathrm{~g} \mathrm{C} \mathrm{m}^{-2} \mathrm{day}^{-1}$, and -3.5 to $5.1 \mathrm{~g} \mathrm{C} \mathrm{m}^{-2}$ day $^{-1}$ at Kirtipur, Simara, and Tarahara sites, respectively (Table 5). The magnitude of daily GPP peaked up to $7.1 \mathrm{~g} \mathrm{C} \mathrm{m}^{-2}$ day $^{-1}$ (Day of Year: DOY 185), $9.7 \mathrm{~g} \mathrm{C} \mathrm{m}^{-2}$ day $^{-1}$ (DOY 181), and $13.3 \mathrm{~g} \mathrm{C} \mathrm{m}^{-2} \mathrm{day}^{-1}$ (DOY 155) during June and July at Kirtipur, Simara, and Tarahara sites, respectively (Table 5). The daily average of ER reached up to $7.3 \mathrm{~g} \mathrm{C}$ $\mathrm{m}^{-2}$ day $^{-1}$ (DOY 181), $9.3 \mathrm{~g} \mathrm{C} \mathrm{m}^{-2}$ day $^{-1}$ (DOY 181), and $13.5 \mathrm{~g} \mathrm{C} \mathrm{m}^{-2}$ day $^{-1}$ (DOY 170) during June at Kirtipur, Simara, and Tarahara sites, respectively (Table 5). The monthly sum of NEE ranged from 28 to $80.1 \mathrm{~g} \mathrm{C} \mathrm{m}^{-2},-7$ to $93.3 \mathrm{~g} \mathrm{C}$ $\mathrm{m}^{-2}$, and -34.7 to $57.6 \mathrm{~g} \mathrm{C} \mathrm{m}^{-2}$ at Kirtipur, Simara, and Tarahara sites, respectively (Table 5).

\subsection{Seasonal variations of evapotranspiration and water use efficiency}

Monthly sum of ET and WUE in Table 6 shows that maximum ET rates were observed in June for the Simara site (109.5 mm) and in August for both Kirtipur (104.2 mm) and Tarahara (139 $\mathrm{mm})$ sites. The value of ET was recorded lowest in March for both Kirtipur (35.1 mm) and Simara $(49.9 \mathrm{~mm})$ sites, whereas, in November for the Tarahara $(55.5 \mathrm{~mm})$ site. During the study period, the pattern of seasonal change in ET was quite similar for all the study sites; nevertheless, ET rate was highest at the Tarahara site and lowest at the Kirtipur site (Fig. 8).
Among the three study sites, the WUE reached its maximum in April (59.6 g C mm$\left.{ }^{-1} \mathrm{ET}\right)$, August (71.6 g C mm${ }^{-1}$ ET), and November (135.1 $\mathrm{g} \mathrm{C} \mathrm{mm}^{-1}$ ET) at Kirtipur, Simara, and Tarahara sites, respectively. Similarly, WUE was minimum in October (34.9 $\mathrm{g} \mathrm{C} \mathrm{mm}^{-1} \mathrm{ET}$ ) for Kirtipur, and in March for both Simara $\left(48.1 \mathrm{~g} \mathrm{C} \mathrm{mm}^{-1} \mathrm{ET}\right)$ and Tarahara ( $\left.69.7 \mathrm{~g} \mathrm{C} \mathrm{mm}^{-1} \mathrm{ET}\right)$ sites. The pattern of seasonal change in WUE was quite similar at all study sites, with the order of Tarahara $>$ Simara $>$ Kirtipur (Fig. 8).

\section{Discussions}

\subsection{Energy balance closure}

Lack of energy balance closure has been widely reported and remains a subject of ongoing research until date (Wilson et al. 2002; Veenendaal et al. 2004; Li et al. 2005; Foken 2008; Stoy et al. 2013). In this present study, the energy balance closures were $56 \%, 61 \%$, and $64 \%$ at Kirtipur, Simara, and Tarahara sites, respectively.

For all the site, the Moore and WPL correction increased the LE, whereas Schotanus correction decreased the sensible heat flux. Given the fact that the sums of the two turbulent fluxes are significantly higher than without the corrections. Furthermore, the soil heat flux values were increased when considering the soil heat flux at the ground surface. The measurement of Rn remains unaffected by any correction procedures. Unless these corrections on turbulent and ground heat fluxes were not applied, the energy imbalance would have been much larger (Mauder et al. 2006).

During the whole measurement period, the experimental imbalances were about $44 \%, 39 \%$, and $36 \%$ of the available energy at Kirtipur, Simara, and Tarahara sites, respectively (Fig. 4). Although the energy balance closures in these sites were not ideal, compared with the long-term imbalances, which are reported from other experiments (Wilson et al. 2002; Li et al. 2005), these values of imbalances are relatively high but not extraordinary. Generally, the results suggested that estimate of the scalar turbulent fluxes of sensible and latent heat were underestimated and/or available energy was overestimated. Finally, we laid out the most common reason that contributed to the imbalance of energy, such as random and systematic errors due to the inadequacies of the micrometeorological measurement systems, systematic instrument bias, neglected energy sinks, heterogeneity of the landscape, low and high-frequency loss of turbulent fluxes, and advection of heat and water vapor along with the energy used in photosynthesis were not taken into consideration in this study ( $\mathrm{Li}$ et al. 2005; Liu et al. 2008; Vourlitis et al. 2008; Cescatti et al. 2012; Bajgain et al. 2018). In addition, soil heat flux measurement is disturbed because soil heat flux plate is placed at only one point, which may not be representative of the whole field 
Table 4 Monthly averages of energy balance components and Bowen ratio for all study sites from March 2016 to November 2016 (**missing data due to malfunction of the sensors and power supply)

\begin{tabular}{|c|c|c|c|c|c|c|}
\hline Months & Study sites & $\mathrm{Rn}\left(\mathrm{W} \mathrm{m}^{-2}\right)$ & $\mathrm{LE}\left(\mathrm{W} \mathrm{m}^{-2}\right)$ & $\mathrm{H}\left(\mathrm{W} \mathrm{m}^{-2}\right)$ & $\mathrm{G}\left(\mathrm{W} \mathrm{m} \mathrm{m}^{-2}\right)$ & Bowen ratio \\
\hline \multirow[t]{3}{*}{ March } & Kirtipur & 71.5 & 31.8 & 34.9 & 2.9 & 1.10 \\
\hline & Simara & 96.7 & 47.2 & 40.1 & 1.0 & 0.85 \\
\hline & Tarahara & 99.3 & 81.4 & 15.0 & 1.8 & 0.18 \\
\hline \multirow[t]{3}{*}{ April } & Kirtipur & 85.4 & 45.8 & 37.0 & 5.1 & 0.81 \\
\hline & Simara & 110.8 & 55.9 & 43.6 & 2.9 & 0.78 \\
\hline & Tarahara & 142.1 & 79.4 & 36.3 & 4.4 & 0.46 \\
\hline \multirow[t]{3}{*}{ May } & Kirtipur & 110.3 & 65.5 & 29.1 & 1.2 & 0.44 \\
\hline & Simara & $* *$ & 80.8 & 34.6 & $* *$ & 0.43 \\
\hline & Tarahara & 151.5 & 104.0 & 28.6 & 3.9 & 0.28 \\
\hline \multirow[t]{3}{*}{ June } & Kirtipur & 134.9 & 83.9 & 27.4 & 2.4 & 0.33 \\
\hline & Simara & 185.1 & 103.7 & 16.5 & 1.8 & 0.16 \\
\hline & Tarahara & 152.6 & 102.6 & 19.5 & 6.2 & 0.19 \\
\hline \multirow[t]{3}{*}{ July } & Kirtipur & 113.2 & 83.5 & 15.6 & 3.0 & 0.19 \\
\hline & Simara & 126.5 & 84.3 & 12.8 & 0.02 & 0.15 \\
\hline & Tarahara & 129.4 & 108.0 & 13.5 & 3.1 & 0.13 \\
\hline \multirow[t]{3}{*}{ August } & Kirtipur & 148.5 & 95.4 & 22.8 & 0.7 & 0.24 \\
\hline & Simara & 165.2 & 101.0 & 13.5 & 1.6 & 0.13 \\
\hline & Tarahara & 158.1 & 127.2 & 7.9 & 3.1 & 0.06 \\
\hline \multirow[t]{3}{*}{ September } & Kirtipur & 98.7 & 66.6 & 15.5 & -2.1 & 0.23 \\
\hline & Simara & 119.3 & 85.0 & 6.5 & -4.8 & 0.08 \\
\hline & Tarahara & 119.9 & 94.9 & 12.7 & 1.6 & 0.13 \\
\hline \multirow[t]{3}{*}{ October } & Kirtipur & 104.5 & 65.0 & 23.3 & -12.2 & 0.36 \\
\hline & Simara & 118.0 & 83.2 & 6.0 & -1.8 & 0.07 \\
\hline & Tarahara & 115.1 & 90.2 & 15.5 & -1.7 & 0.17 \\
\hline \multirow[t]{3}{*}{ November } & Kirtipur & $* *$ & $* *$ & $* *$ & $* *$ & $* *$ \\
\hline & Simara & 101.8 & 67.0 & 12.7 & -2.8 & 0.19 \\
\hline & Tarahara & 89.6 & 52.4 & 26.6 & -5.4 & 0.51 \\
\hline
\end{tabular}

as the soil structure above the plate is definitely different from the surrounding soil, and the placement of the plate is very close to the surface inhibiting water transport in the soil (Mauder et al. 2006; Acharya et al. 2019).

\subsection{Diurnal and seasonal dynamics of energy fluxes}

The diurnal variation of the aforementioned energy flux components showed a linear relationship with the incoming solar radiation as their values were peak during mid-day. The differences in net radiation between the three sites were mainly due to the differences in the albedo of the land surfaces surrounding these three sites, inferring seasonal changes in radiation property. Net radiation was relatively lower in July at all the study sites because this month is characterized by massive clouds with high precipitation and humidity.

Both $\mathrm{Rn}$ and precipitation were higher at Tarahara and Simara sites, so their counterpart LE was also higher for these sites than the Kirtipur site. During March to May, energy partitioning into latent and sensible heat flux was almost same, whereas energy partitioning into latent heat flux was much higher than sensible heat flux from June to November at all study sites. The latent heat flux was higher than sensible heat flux during the growing season in all the study sites similar to those reported in several previous studies (Liu et al. 2008; Sun et al. 2010; Rodda et al. 2016; Wagle et al. 2016). This is because during the growing season, as rainfall wets the ground surface, latent heat flux increases (Liu et al. 2008). The declining trends of soil heat flux over the growing season at all sites are mainly due to the dense vegetation cover at this season (Wagle and Kakani 2014a).

The main factor that controls the partitioning of the available energy was soil moisture in combination with low VPD effects on LE during the wet months. The opposite was true for the drier months when $\mathrm{H}$ dominated (Odongo et al. 2016). Precipitation sensitive ecosystem has typical characteristics in shifting the partitioning of available energy into $\mathrm{H}$ and LE, whereby limited precipitation causes a decrease in soil moisture, resulting to decrease in the evaporation component of LE (Chen et al. 2009). Meanwhile, higher VPD with high temperature and net radiation causes the reduction in the stomatal 
Fig. 5 Monthly diurnal patterns of net radiation, latent heat flux, sensible heat flux, and soil heat flux from March 2016 to

November 2016 at a Kirtipur, b Simara, and $\mathbf{c}$ Tarahara sites (incomplete lines indicate the data gap)
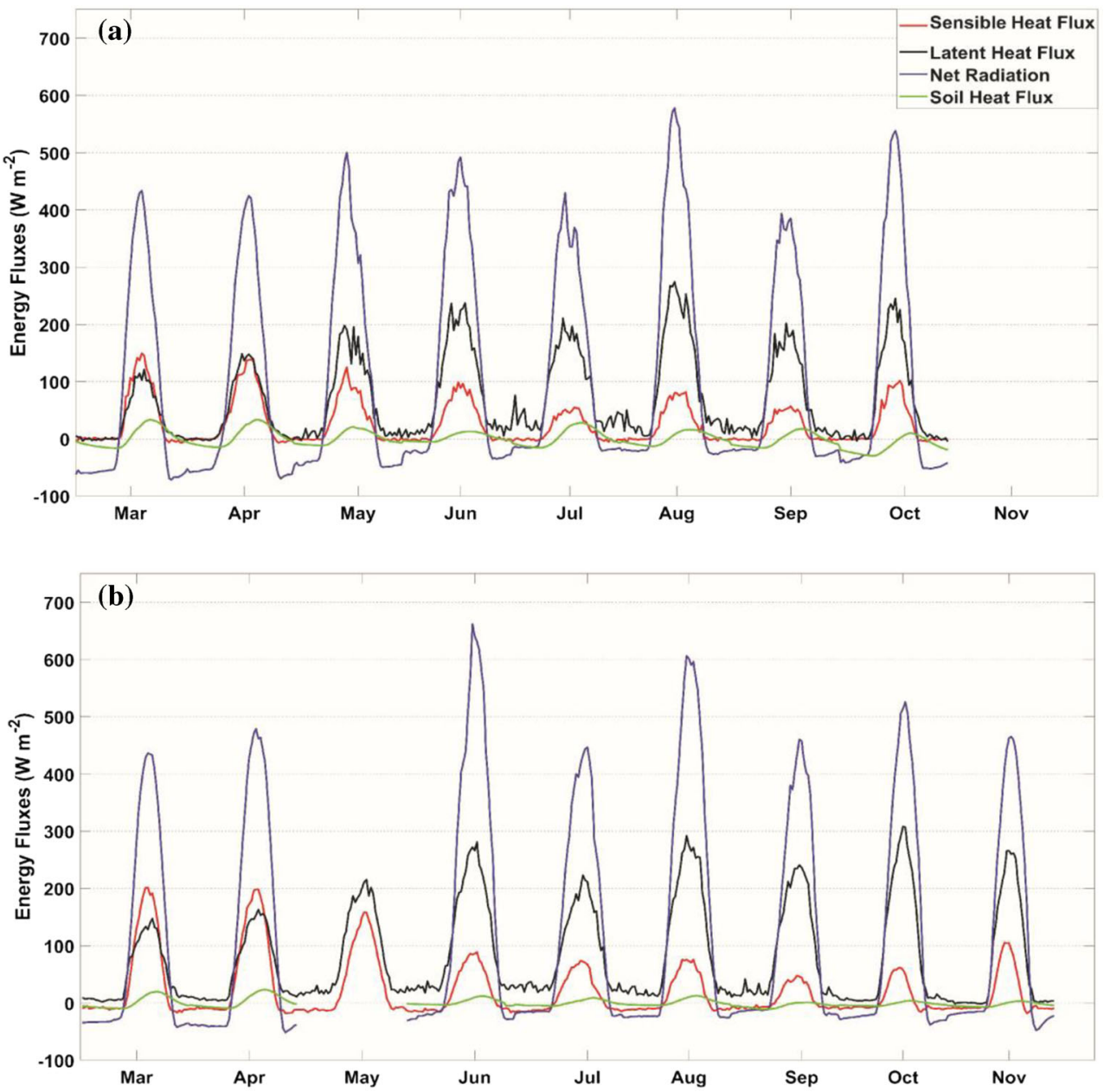

700 (c)

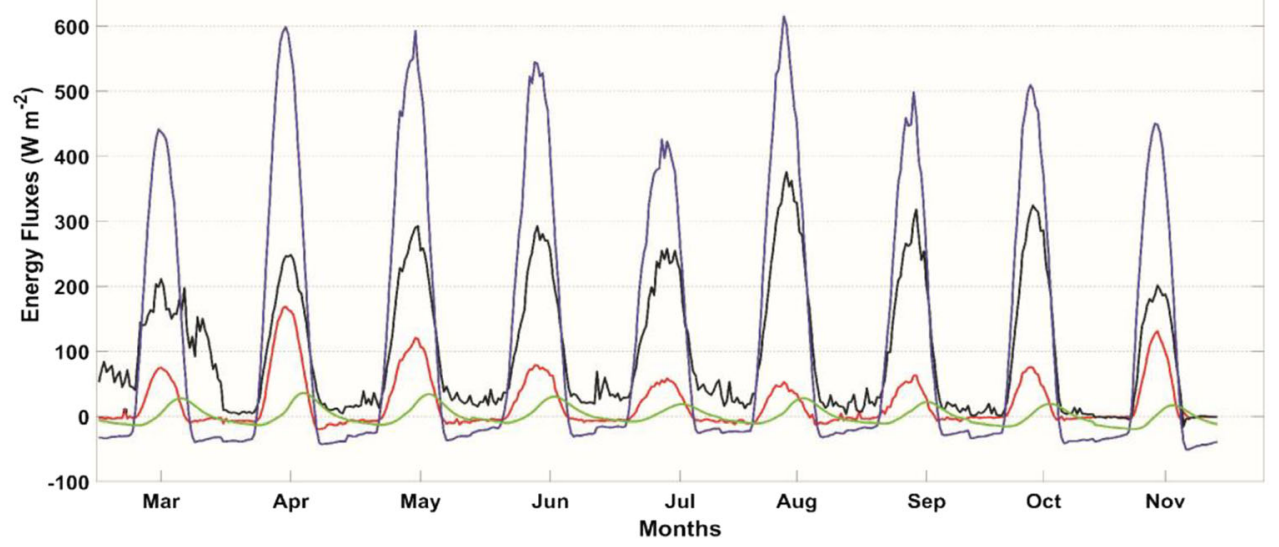

conduction of the foliage, resulting in a reduction in the transpiration component of LE (Odongo et al. 2016). LE was the dominant turbulent flux on the seasonal scale, and the contribution of soil heat flux was very less in energy partitioning. Hence, it can be concluded that the energy partitioning is more sensitive to the climatic factors.

\subsection{Diurnal and seasonal dynamics of NEE}

In this study, the maximum $\mathrm{CO}_{2}$ uptake rates were observed for all sites during noon due to the peak photosynthetic activity. At all the study sites, the $\mathrm{CO}_{2}$ uptake rates were higher as the plant grew, reaching their maximum 
Fig. 6 Monthly diurnal patterns of net ecosystem $\mathrm{CO}_{2}$ exchange (NEE) from March 2016 to November 2016 at Kirtipur, Simara, and Tarahara sites

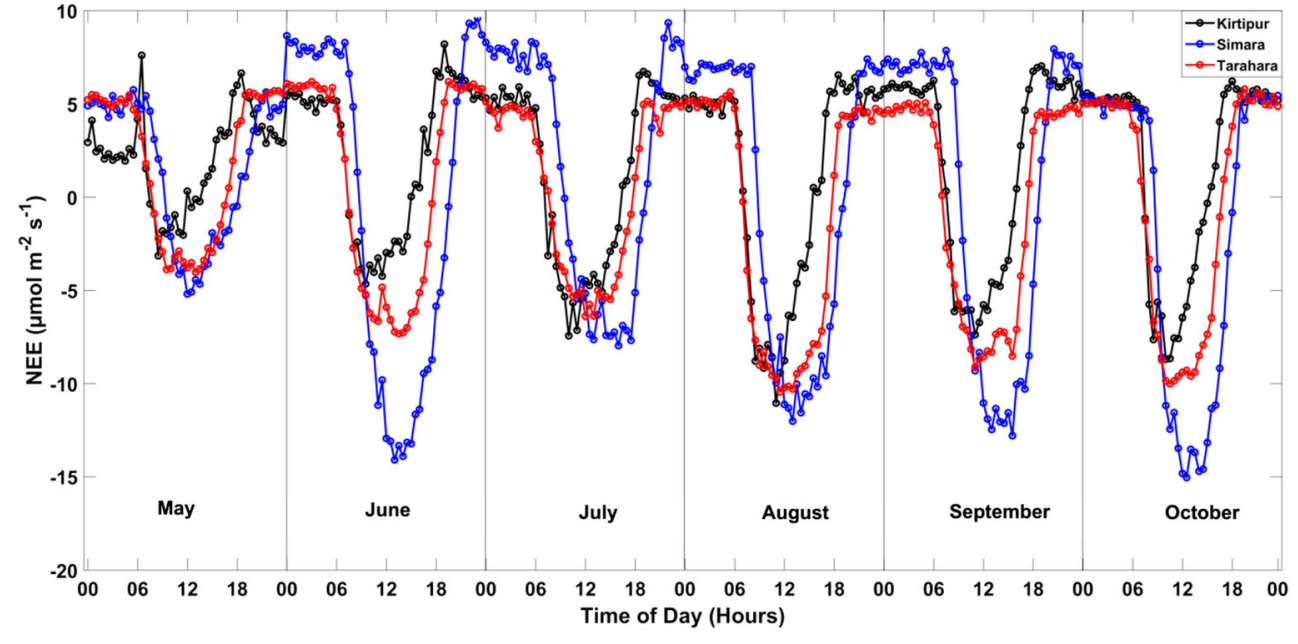

values during the peak growth and gradually lowered after the growing season due to the vegetation senescence (Bajgain et al. 2018). The difference in $\mathrm{CO}_{2}$ uptake rates observed in these three study sites was due to the different land cover types with contrast in their surrounding vegetations. The magnitudes of diurnal variation of NEE were largest in August at Kirtipur and Tarahara sites and in October at the Simara site. The observed NEE rates were highest during peak growing season because in this season, aboveground biomass is dense and photosynthetic activities of plants are higher. The maximum $\mathrm{CO}_{2}$ uptake rates observed at three study sites were within the range reported previously in different grassland and cropland areas. For example, these maximum $\mathrm{CO}_{2}$ uptake rates were 5-14 $\mu \mathrm{mol} \mathrm{m} \mathrm{m}^{-2} \mathrm{~s}^{-1}$ on northern temperate grassland near Lethbridge, Alberta, Canada (Flanagan et al. 2002); 6-13 $\mu \mathrm{mol} \mathrm{m} \mathrm{m}^{-2} \mathrm{~s}^{-1}$ on natural Agropyron-Koeleria grassland (Ripley and Saugier 1978); and $15.5 \mu \mathrm{mol} \mathrm{m}^{-2} \mathrm{~s}^{-1}$ on the southern plains prairie, North America (Sims and Bradford 2001). In addition, the maximum $\mathrm{CO}_{2}$ uptake rate reported on cropland and degraded grassland surface in a semi-arid area of Northeastern China were $17.81 \mu \mathrm{mol} \mathrm{m}^{-2} \mathrm{~s}^{-1}$ and $13.36 \mu \mathrm{mol} \mathrm{m} \mathrm{m}^{-2} \mathrm{~s}^{-1}$ (Liu et al. 2008), respectively. The maximum $\mathrm{CO}_{2}$ uptake rates observed in our sites were lower than values reported for Switchgrass $(36.9 \mu \mathrm{mol}$ $\left.\mathrm{m}^{-2} \mathrm{~s}^{-1}\right)$ and Sorghum $\left(29.6 \mu \mathrm{mol} \mathrm{m} \mathrm{m}^{-2} \mathrm{~s}^{-1}\right)$ in the southcentral research station, Chikasa (Wagle et al. 2015).

During the growing season, the fluctuations in the value of GPP were higher at all the study sites, which may be due to the less availability of photosynthetic radiation because of cloudy and rainy days. Furthermore, the pattern of seasonal variation of ER was fairly similar to GPP at all the study sites. The minimum values for daily averaged NEE (as aforementioned in Section 3.4) were small as compared with previous studies conducted at many croplands and grasslands, as mentioned in the earlier paragraph.
Fig. 7 Seasonal patterns of net ecosystem $\mathrm{CO}_{2}$ exchange (NEE), ecosystem respiration (ER), and gross primary production (GPP) during March 2016 to November 2016 at a Kirtipur, b Simara, and c Tarahara sites (incomplete lines indicate the data gap)
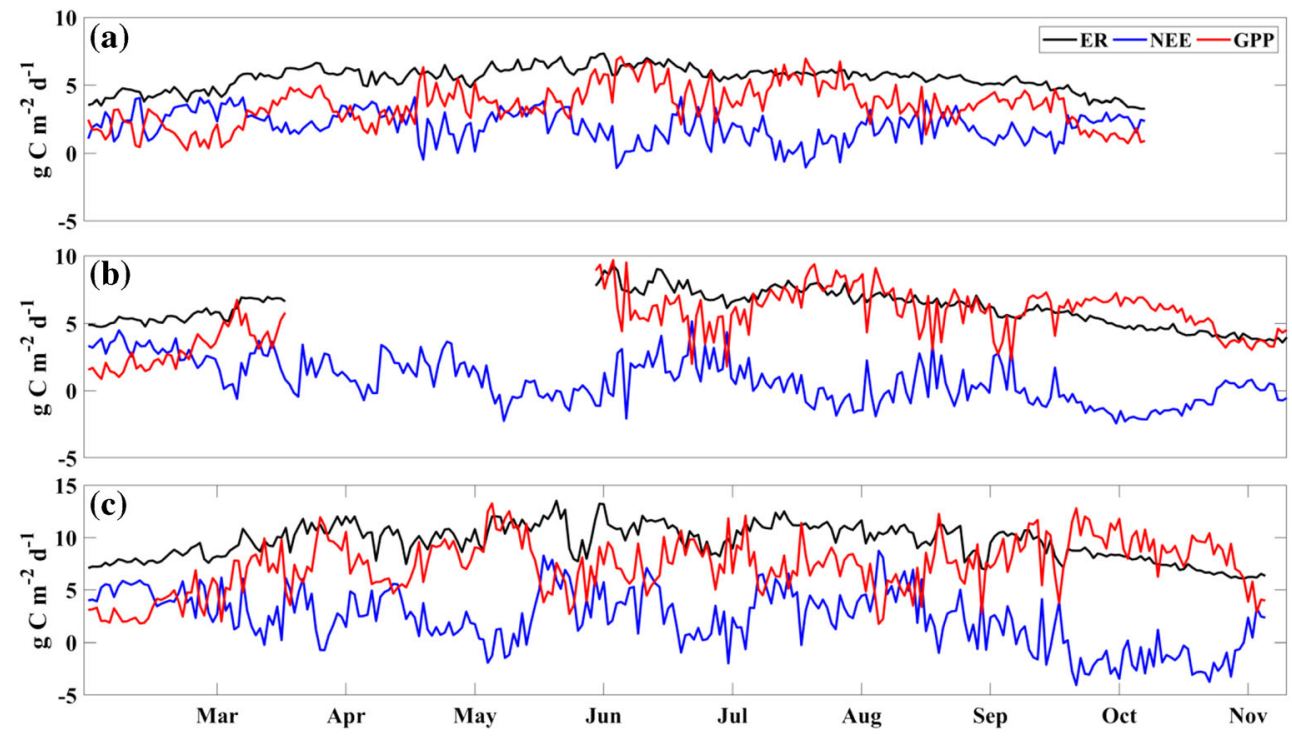
Table 5 Monthly sums of net ecosystem $\mathrm{CO}_{2}$ exchange (NEE, $\mathrm{g} \mathrm{C} \mathrm{m}^{-2}$ ), ecosystem respiration (ER, $\mathrm{g} \mathrm{C} \mathrm{m}^{-2}$ ), and gross primary production (GPP, $\mathrm{g} \mathrm{C} \mathrm{m}^{-2}$ ) during March 2016 to November 2016 at Kirtipur, Simara, and Tarahara sites $(* *$ missing data due to malfunction of the sensors and power supply)

\begin{tabular}{|c|c|c|c|c|c|c|c|c|c|}
\hline \multirow[t]{2}{*}{ Months } & \multicolumn{3}{|c|}{ Kirtipur } & \multicolumn{3}{|l|}{ Simara } & \multicolumn{3}{|c|}{ Tarahara } \\
\hline & NEE & ER & GPP & NEE & ER & GPP & NEE & ER & GPP \\
\hline March & 80.1 & 133.4 & 53.3 & 93.3 & 165.0 & 71.1 & 47.7 & 246.9 & 199.2 \\
\hline April & 76.5 & 173.6 & 97.2 & 47.6 & $* *$ & $* *$ & 26.7 & 303.9 & 277.1 \\
\hline May & 68.6 & 174.3 & 105.8 & 50.8 & $* *$ & $* *$ & 57.6 & 310.6 & 253.0 \\
\hline June & 75.8 & 194.0 & 118.1 & -7.0 & $* *$ & $* *$ & 23.7 & 331.3 & 307.5 \\
\hline July & 43.5 & 191.1 & 147.6 & 59.3 & 229.2 & 169.9 & 17.2 & 320.3 & 303.1 \\
\hline August & 28.0 & 181.4 & 153.3 & -6.2 & 229.1 & 235.3 & -34.7 & 343.3 & 378.1 \\
\hline September & 60.1 & 164.6 & 104.6 & 23.0 & 186.0 & 166.9 & -10.3 & 296.6 & 306.9 \\
\hline October & 58.5 & 138.4 & 79.9 & -37.0 & 166.1 & 203.1 & -3.8 & 276.0 & 279.8 \\
\hline November & $* *$ & $* *$ & $* *$ & -12.1 & 124.2 & 136.3 & -33.8 & 206.7 & 240.6 \\
\hline
\end{tabular}

Figure 7 shows that the daily averaged NEE was mostly positive at all the days during the study period at the Kirtipur site, indicating that the ecosystem at this site is a source for $\mathrm{CO}_{2}$. The ecosystem at the Kirtipur site was carbon source for almost all days during the study period and even in the growing season. This could be due to its suburban locality, where the main sources of $\mathrm{CO}_{2}$ could be the consumption of fossil fuels and other anthropogenic activities. This result is in agreement with many previous studies that were carried out in other suburban areas which reported that $\mathrm{CO}_{2}$ flux was positive throughout the day and year in such areas (Moriwaki and Kanda 2004; Ward et al. 2015). The suburban Kirtipur site has a combination of building areas and vegetation cover where the level of anthropogenic and biogenic activities determines and controls the fluxes (Ward et al. 2015). The photosynthetic uptake is greatest at the noon of the growing season days associated with maximal PAR. The pattern of diurnal $\mathrm{CO}_{2}$ fluxes is also similar to the other two sites. Despite the suburban vegetation cover at this site, the net daily flux is usually positive. Hence, suburban vegetation did not have enough potential to reduce the overall release of $\mathrm{CO}_{2}$ at the Kirtipur site, however, plays a key role for compensating the anthropogenic impact.

The daily averaged NEE was positive throughout the majority of days and negative during the growing season at Simara and Tarahara sites, suggesting that the ecosystem at these two sites are a source of $\mathrm{CO}_{2}$ except for the growing season. During the growing season, photosynthetic activities are rapid than respiration for the growths of green leaves and aboveground biomass (Wagle and Kakani 2014b).

Among the three study sites, the ecosystem at the Simara site was net carbon sink in June, August, October, and November, whereas the ecosystem at the Tarahara site was a net carbon sink from August to November. The ecosystem at the Kirtipur site was a carbon source even in the growing season. Hence, the difference in carbon fluxes between three sites suggests that the carbon sink potential of the Simara site was smaller than the Tarahara site during the growing season. Consequently, the ecosystems of all the study sites were carbon source when accounted by offsetting the growing season carbon sink magnitude for the studied time scale.
Table 6 Monthly sums of evapotranspiration (ET, $\mathrm{mm}$ ) and water use efficiency (WUE, g C $\mathrm{mm}^{-1} \mathrm{ET}$ ) at Kirtipur, Simara, and Tarahara sites during the study period $(* *$ denotes missing data due to malfunction of the sensors and power supply)

\begin{tabular}{|c|c|c|c|c|c|c|}
\hline \multirow[t]{2}{*}{ Months } & \multicolumn{2}{|c|}{ Kirtipur } & \multicolumn{2}{|c|}{ Simara } & \multicolumn{2}{|c|}{ Tarahara } \\
\hline & $\mathrm{ET}$ & WUE & ET & WUE & ET & WUE \\
\hline March & 35.1 & 48.2 & 49.9 & 48.1 & 89.0 & 69.7 \\
\hline April & 48.7 & 59.6 & 56.3 & $* *$ & 83.9 & 99.8 \\
\hline May & 71.7 & 48.2 & 87.0 & $* *$ & 113.6 & 72.3 \\
\hline June & 88.7 & 41.7 & 109.5 & $* *$ & 108.5 & 87.2 \\
\hline July & 91.5 & 51.8 & 90.5 & 62.2 & 118.0 & 89.7 \\
\hline August & 104.2 & 46.2 & 108.6 & 71.6 & 139.0 & 88.5 \\
\hline September & 70.9 & 47.0 & 87.9 & 59.1 & 100.4 & 98.8 \\
\hline October & 71.0 & 34.9 & 91.2 & 69.9 & 98.5 & 91.3 \\
\hline November & $* *$ & $* *$ & 70.1 & 60.1 & 55.5 & 135.1 \\
\hline
\end{tabular}


Fig. 8 Seasonal patterns of evapotranspiration (ET) and water use efficiency (WUE) at Kirtipur, Simara, and Tarahara sites during the study period (incomplete lines indicate the data gap)
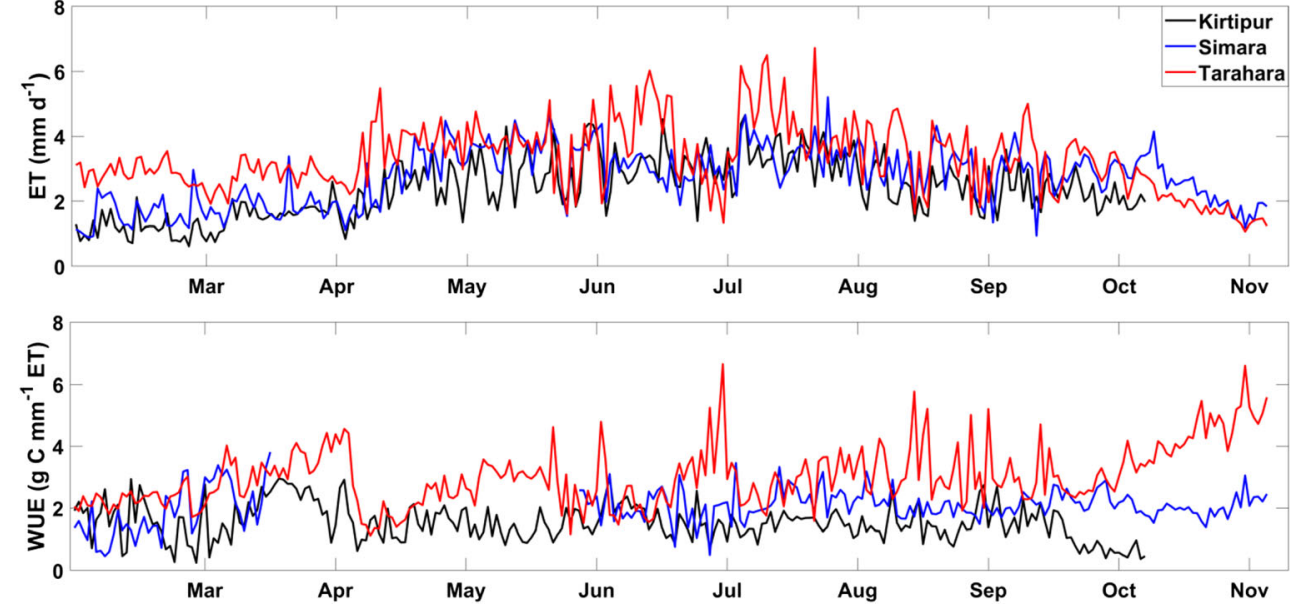

\subsection{Seasonal variations of evapotranspiration and water use efficiency}

Over the entire study period, ET was found in the order of Tarahara $>$ Simara $>$ Kirtipur. This could be because the precipitation at the Simara site was higher than that of the Kirtipur site and lower than the Tarahara site. Moreover, higher precipitation favors the canopy development at the Tarahara site and least at the Kirtipur site, which also impacted ET rates at these sites. This result is in agreement with the previous study which demonstrated that precipitation and canopy development greatly affected the magnitude of ET (Wagle et al. 2016). At all the study sites, ET rates showed a clear pattern of seasonality, increasing with plant growth and maximum ET rates during the growing season when plant growth is peaked (Wagle et al. 2016).

During the study period, WUE at the Simara site was lower than that of the Tarahara site but higher than the Kirtipur site. This result shows that the Kirtipur site was slightly more efficient than the Simara site, and both Kirtipur and Simara sites were more efficient than the Tarahara site when using water to gain carbon. Usually, WUE was found higher during the growing season when plant growth reached its peak as full canopy closure reduces the amount of radiation reaching the ground surface which ultimately reduces soil evaporation (Wagle et al. 2016).

\section{Conclusion}

This study provides information about the seasonal and diurnal variations of carbon dioxide and energy fluxes over three land cover types of Nepal. For this purpose, carbon dioxide and energy fluxes were measured from March 2016 to November 2016 by using the eddy covariance method. The energy balance closures, which provides the plausibility of fluxes that were measured from the eddy covariance measurement system (Wagle et al. 2015), were found to be $56 \%, 61 \%$, and $64 \%$ at Kirtipur, Simara, and Tarahara sites, respectively. Although, energy balance closures for these sites were not ideal; yet, the obtained values were within the ranges that were reported in previous studies (Wilson et al. 2002; $\mathrm{Li}$ et al. 2005). The main factor that controls the partitioning of the available energy was soil moisture in combination with low VPD effects on LE during the wet months. The opposite was true for the drier months when $\mathrm{H}$ dominated (Odongo et al. 2016). Also, it was observed that energy partitioning is more sensitive to climatic factors. LE was the dominant turbulent flux on the seasonal scale, and the contribution of soil heat flux was very less in energy partitioning.

Among the three study sites, the ecosystem at the Tarahara site was a good carbon sink; the ecosystem at the Simara site was a small carbon sink whereas the ecosystem at the Kirtipur site was a carbon source in the growing season. All three different land cover ecosystems were carbon source when accounted for the annual time scale. This research will pave to ease the fellow researchers to identify the potential carbon sinks and sources in the study region. Furthermore, when evaluated in and for long terms, this kind of research will definitely help in building a consensus and consortium, which provides a base of trustworthy eddy covariance datasets to represent ecosystem dynamics, in whichever scale the intended research may indicate towards.

Acknowledgments The authors would like to acknowledge Mr Nitesh Khadka, Mr Shankar Sharma, Mr Bhaskar Shrestha, and Mr Ramhari Acharya for their help and support during this research. We are highly obliged to constructive suggestions and comments from anonymous reviewers.

Funding information This research has been funded by the Strategic Priority Research Program of Chinese Academy of Sciences (Grant No. XDA20060101), the National Natural Science Foundation of China (Grant No. 91837208 , 41661144043, 91637312), and the Chinese Academy of Sciences (Grant No. QYZDJ-SSW-DQC019). 
Open Access This article is distributed under the terms of the Creative Commons Attribution 4.0 International License (http:// creativecommons.org/licenses/by/4.0/), which permits unrestricted use, distribution, and reproduction in any medium, provided you give appropriate credit to the original author(s) and the source, provide a link to the Creative Commons license, and indicate if changes were made.

\section{References}

Acharya RH, Sigdel M, Ma Y, Wang B (2019) Diurnal and seasonal variation of heat fluxes over an agricultural field in southeastern Nepal. Theor Appl Climatol 1-12

Bajgain R, Xiao X, Basara J, Wagle P, Zhou Y, Mahan H, Gowda P, McCarthy HR, Northup B, Neel J, Steiner J (2018) Carbon dioxide and water vapor fluxes in winter wheat and tallgrass prairie in central Oklahoma. Sci Total Environ 644:1511-1524

Baldocchi D (1997) Measuring and modelling carbon dioxide and water vapour exchange over a temperate broad-leaved forest during the 1995 summer drought. Plant Cell Environ 20:1108-1122. https:// doi.org/10.1046/j.1365-3040.1997.d01-147.x

Beringer J, Tapper N (2002) Surface energy exchanges and interactions with thunderstorms during the Maritime Continent Thunderstorm Experiment (MCTEX). J Geophys Res Atmos 107:1-13. https:// doi.org/10.1029/2001JD001431

Cescatti A, Marcolla B, Vannan SKS et al (2012) Intercomparison of MODIS albedo retrievals and in situ measurements across the global FLUXNET network. Remote Sens Environ 121:323-334

Chen S, Chen J, Lin G, Zhang W, Miao H, Wei L, Huang J, Han X (2009) Energy balance and partition in Inner Mongolia steppe ecosystems with different land use types. Agric For Meteorol 149:1800-1809

Climate Change: Vital Signs of the Planet (2019) Carbon Dioxide Concentration | NASA Global Climate Change. Online Available at: https://climate.nasa.gov/vital-signs/carbon-dioxide/ (Accessed 16 Jun 2019)

DHM (2017) Observed Climate Trend Analysis in the Districts and Physiographic Regions of Nepal (1971-2014). Department of Hydrology and Meteorology, Kathmandu

Dickinson RE, Henderson-Sellers A, Rosenzweig C, Sellers PJ (1991) Evapotranspiration models with canopy resistance for use in climate models, a review. Agric For Meteorol 54:373-388. https://doi.org/ 10.1016/0168-1923(91)90014-H

Dugas WA, Heuer ML, Mayeux HS (1999) Carbon dioxide fluxes over bermudagrass, native prairie, and sorghum. Agric For Meteorol 93: 121-139. https://doi.org/10.1016/S0168-1923(98)00118-X

Finkelstein PL, Sims PF (2001) Sampling error in eddy correlation flux measurements. J Geophys Res Atmos 106:3503-3509

Flanagan LB, Wever LA, Carlson PJ (2002) Seasonal and interannual variation in carbon dioxide exchange and carbon balance in a northern temperate grassland. Glob Chang Biol 8:599-615

Foken T (2008) The energy balance closure problem: an overview. Ecol Appl 18:1351-1367

Foken T, Oncley S (1995) Workshop on instrumental and methodical problems of land surface flux measurements. Bull Am Meteorol Soc 76:1191-1224

Foken T, Göockede M, Mauder M, et al (2004) Post-field data quality control. In: Handbook of micrometeorology. Springer, pp 181-208

Gautam M, Bhattarai J (2013) Study on the soil corrosivity towards the buried-structures in soil environment of Tanglaphant-Tribhuvan University Campus-Balkhu areas of Kirtipur. Nep J Sci Technol $14: 65-72$
Gentine P, Entekhabi D, Heusinkveld B (2012) Systematic errors in ground heat flux estimation and their correction. Water Resour Res 48:1-15. https://doi.org/10.1029/2010WR010203

Hao Y, Wang Y, Huang X, Cui X, Zhou X, Wang S, Niu H, Jiang G (2007) Seasonal and interannual variation in water vapor and energy exchange over a typical steppe in Inner Mongolia, China. Agric For Meteorol 146:57-69. https://doi.org/10.1016/j.agrformet.2007.05. 005

Khadka D, Lamichhane S, Shrestha SR, Pant BB (2017) Evaluation of soil fertility status of regional agricultural Research Station, Tarahara, Sunsari, Nepal. Eur J Soil Sci 6:295-306

Khadka D, Lamichhane S, Bhurer KP, Chaudhary JN, Ali MF, Lakhe L (2018) Soil Fertility Assessment and Mapping of Regional Agricultural Research Station, Parwanipur, Bara, Nepal. J Nep Agric Res Counc 4:33-47

Kormann R, Meixner FX (2001) An analytical footprint model for nonneutral stratification. Bound-Layer Meteorol 99:207-224

Li ZQ, Yu GR, Wen XF et al (2005) Energy balance closure at ChinaFLUX sites. Sci China Ser D Earth Sci. https://doi.org/10. 1360/05zd0005

Liu H, Peters G, Foken T (2001) New equations for sonic temperature variance and buoyancy heat flux with an omnidirectional sonic anemometer. Bound-Layer Meteorol 100:459-468

Liu H, Tu G, Fu C, Shi L (2008) Three-year variations of water, energy and $\mathrm{CO} 2$ fluxes of cropland and degraded grassland surfaces in a semi-arid area of Northeastern China. Adv Atmos Sci 25:10091020

Mahrt L, Vickers D, Andreas EL, Khelif D (2012) Sensible heat flux in near-neutral conditions over the sea. J Phys Oceanogr 42:1134-1142

Mauder M, Foken T (2011) Documentation and instruction manual of the eddy covariance software package TK3, Univ. Bayreuth, Abt Mikrometeorologie

Mauder M, Liebethal C, Göckede M, Leps JP, Beyrich F, Foken T (2006) Processing and quality control of flux data during LITFASS-2003. Bound-Layer Meteorol 121:67-88

Mauder M, Cuntz M, Drüe C, Graf A, Rebmann C, Schmid HP, Schmidt M, Steinbrecher R (2013) A strategy for quality and uncertainty assessment of long-term eddy-covariance measurements. Agric For Meteorol 169:122-135

Mielnick PC, Dugas WA, Johnson HB, Polley HW, Sanabria J (2001) Net grassland carbon flux over a subambient to superambient $\mathrm{CO}_{2}$ gradient. Glob Chang Biol 7:747-754. https://doi.org/10.1046/j.13541013.2001.00445.x

Mauder M (2002) Auswertung von Turbulenzmessgerätevergleichen unter besonderer Berücksichtigung von EBEX-2000. Master Thesis, Abt. Mikrometeorologie, Universität Bayreuth, Bayreuth, pp 86

Moffat AM, Papale D, Reichstein M, Hollinger DY, Richardson AD, Barr AG, Beckstein C, Braswell BH, Churkina G, Desai AR, Falge E, Gove JH, Heimann M, Hui D, Jarvis AJ, Kattge J, Noormets A, Stauch VJ (2007) Comprehensive comparison of gap-filling techniques for eddy covariance net carbon fluxes. Agric For Meteorol 147:209-232

Moore CJ (1986) Frequency response corrections for eddy correlation systems. Bound-Layer Meteorol 37:17-35

Moriwaki R, Kanda M (2004) Seasonal and diurnal fluxes of radiation, heat, water vapor, and carbon dioxide over a suburban area. J Appl Meteorol 43:1700-1710

Odongo VO, Van Der Tol C, Becht R et al (2016) Energy partitioning and its controls over a heterogeneous semi- arid shrubland ecosystem in the Lake Naivasha Basin. Kenya. 9:1358-1375. https://doi.org/10. 1002/eco.1732

Reichstein M, Falge E, Baldocchi D, Papale D, Aubinet M, Berbigier P, Bernhofer C, Buchmann N, Gilmanov T, Granier A, Grunwald T, Havrankova K, Ilvesniemi H, Janous D, Knohl A, Laurila T, Lohila A, Loustau D, Matteucci G, Meyers T, Miglietta F, Ourcival JM, 
Pumpanen J, Rambal S, Rotenberg E, Sanz M, Tenhunen J, Seufert G, Vaccari F, Vesala T, Yakir D, Valentini R (2005) On the separation of net ecosystem exchange into assimilation and ecosystem respiration: review and improved algorithm. Glob Chang Biol 11: 1424-1439

Ripley EA, Saugier B (1978) Biophysics of a natural grassland: evaporation. J Appl Ecol 15:459-479

Robertson GP, Paul EA, Harwood RR (2000) Greenhouse gases in intensive agriculture: contributions of individual gases to the radiative forcing of the atmosphere. Science (80-) 289:1922-1925

Rodda SR, Thumaty KC, Jha CS, Dadhwal VK (2016) Seasonal variations of carbon dioxide, water vapor and energy fluxes in tropical Indian mangroves. Forests 7(2):35-41

Saito M, Miyata A, Nagai H, Yamada T (2005) Seasonal variation of carbon dioxide exchange in rice paddy field in Japan. Agric For Meteorol 135:93-109. https://doi.org/10.1016/j.agrformet.2005.10. 007

Schmid HP, Cleugh HA, Grimmond CSB, Oke TR (1991) Spatial variability of energy fluxes in suburban terrain. Bound-Layer Meteorol 54:249-276

Schmid HP (1997) Experimental design for flux measurements: matching scales of observations and fluxes. Agric For Meteorol 87(2-3):179200

Sims PL, Bradford JA (2001) Carbon dioxide fluxes in a southern plains prairie. Agric For Meteorol 109:117-134

Stocker TF, Qin D, Plattner G, et al (2013) Technical summary. In: Climate change 2013: the physical science basis. Contribution of Working Group I to the Fifth Assessment Report of the Intergovernmental $\mathrm{Pa}$. doi: https://doi.org/10.1017/ CBO9781107415324.004

Stoy PC, Mauder M, Foken T et al (2013) A data-driven analysis of energy balance closure across FLUXNET research sites: the role of landscape scale heterogeneity. Agric For Meteorol 171:137-152

Sun G, Noormets A, Gavazzi MJ, McNulty SG, Chen J, Domec JC, King JS, Amatya DM, Skaggs RW (2010) Energy and water balance of two contrasting loblolly pine plantations on the lower coastal plain of North Carolina, USA. For Ecol Manag 259:1299-1310

Veenendaal EM, Kolle O, Lloyd J (2004) Seasonal variation in energy fluxes and carbon dioxide exchange for a broad-leaved semi-arid savanna (Mopane woodland) in Southern Africa. Glob Chang Biol $10: 318-328$

Vourlitis GL, de Souza Nogueira J, de Almeida Lobo F, et al (2008) Energy balance and canopy conductance of a tropical semideciduous forest of the southern Amazon Basin. Water Resour Res 44
Wagle P, Kakani VG (2014a) Growing season variability in evapotranspiration, ecosystem water use efficiency, and energy partitioning in switchgrass. Ecohydrology 7:64-72. https://doi.org/10.1002/eco. 1322

Wagle P, Kakani VG (2014b) Seasonal variability in net ecosystem carbon dioxide exchange over a young Switchgrass stand. GCB Bioenergy 6:339-350

Wagle P, Kakani VG, Huhnke RL (2015) Net ecosystem carbon dioxide exchange of dedicated bioenergy feedstocks: switchgrass and high biomass sorghum. Agric For Meteorol 207:107-116

Wagle P, Kakani VG, Huhnke RL (2016) Evapotranspiration and ecosystem water use efficiency of switchgrass and high biomass sorghum. Agron J 108:1007-1019

Ward HC, Kotthaus S, Grimmond CSB, Bjorkegren A, Wilkinson M, Morrison WTJ, Evans JG, Morison JIL, Iamarino M (2015) Effects of urban density on carbon dioxide exchanges: observations of dense urban, suburban and woodland areas of southern England. Environ Pollut 198:186-200

Webb EK, Pearman GI, Leuning R (1980) Correction of flux measurements for density effects due to heat and water vapour transfer. Q J R Meteorol Soc 106:85-100

Wilczak JM, Oncley SP, Stage SA (2001) Sonic anemometer tilt correction algorithms. Bound-Layer Meteorol 99:127-150

Wilson K, Goldstein A, Falge E, Aubinet M, Baldocchi D, Berbigier P, Bernhofer C, Ceulemans R, Dolman H, Field C, Grelle A, Ibrom A, Law BE, Kowalski A, Meyers T, Moncrieff J, Monson R, Oechel W, Tenhunen J, Valentini R, Verma S (2002) Energy balance closure at FLUXNET sites. Agric For Meteorol 113:223-243. https://doi.org/ 10.1016/S0168-1923(02)00109-0

Woodward FI (1998) Vegetation-climate feedbacks in a greenhouse world. Philos Trans R Soc Lond B Biol Sci 353:29-39. https://doi. org/10.1098/rstb.1998.0188

Xu T, Bateni SM, Liang S et al (2014) Estimation of surface turbulent heat fluxes via variational assimilation of sequences of land surface temperatures from Geostationary Operational Environmental Satellites. J Geophys Res Atmos 119:10-780

Zhang SF, Wyngaard JC, Businger JA, Oncley SP (1986) Response characteristics of the UW sonic anemometer. J Atmos Ocean Technol 3: 315-323

Publisher's note Springer Nature remains neutral with regard to jurisdictional claims in published maps and institutional affiliations. 